\title{
PERMAINAN EDUKATIF DAN PERKEMBANGAN KOGNITIF ANAK USIA DINI
}

\author{
Nina Veronica \\ Universitas Muhammadiyah Surabaya \\ veronicanina44@gmail.com
}

\begin{abstract}
ABSTRAK
Perkembangan kognitif merupakan salah satu aspek perkembangan yang perlu untuk diberikan stimulasi sejak anak usia dini. Perkembangan kognitif berhubungan dengan pola berfikir, pemecahan masalah dan imajinasi anak. Perkembangan kognitif anak dapat dikembangkan melalui permainan, karena bermain merupakan hal yang dekat dengan anak dan dunia anak adalah dunia bermain. Permainan tidak semuanya berdampak baik bagi anak, sehingga orang tua dan guru harus mengetahui tujuan dan manfaat dari permainan itu sendiri bagi anak. Dalam kajian teori berikut akan membahas tentang permainan yang sesuai dengan kebutuhan anak terutama untuk mengembangkan aspek kognitif anak usia dini.
\end{abstract}

Kata Kunci: permainan edukatif, kognitif, anak usia dini

\section{ABSTRACT}

Cognitive development is one of the aspects of development that need to be given stimulation since early childhood. Cognitive development-related patterns of thinking, problem solving and imagination of the child. Cognitive development of children can be developed through game play, because it is close to the child and the child's world is the world of the play. Not all games have an impact is good for kids, so parents and teachers should know the purpose and benefits of the game itself for the child. In theory the following will discuss about the game that suits your child's needs particularly to develop the cognitive aspects of early childhood.

Keywords: educational games, cognitive, early childhood

\section{PENDAHULUAN}

Usia dini merupakan masa dimana anak belum mampu mengembangkan potensi yang ada pada dirinya. Peran dari orang tua, guru atau masyarakat merupakan faktor untuk membantu anak dalam mengembangkan potensinya. Kebanyakan orang tua melimpahkan kepada sekolah untuk mengembangkan potensi anak, sedangkan menurut Sujiono (2013) pendidikan pada anak usia dini pada dasarnya meliputi seluruh upaya dan tindakan yang dilakukan pendidik dan orang tua menciptakan aura dan lingkungan dimana anak dapat mengeksplorasi pengalaman yang memberikan kesempatan untuk mengamati, meniru dan mencoba dengan melibatkan potensi dan kecerdasan anak. Untuk itu pentingnya pendidikan bagi anak usia dini baik itu formal, informal dan nonformal harus tetap terlaksana guna mengembangkan pertumbuhan dan aspek perkembangan kearah yang lebih baik untuk masa yang akan datang. 
Prinsip pendidikan anak usia dini menjadi salah satu yang perlu diperhatikan oleh lembaga diantaranya a) mengembangakan kebutuhan anak b) belajar melalui bermain c) lingkungan yang kondusif d) pembalajaran dalam bermain e) mengambangkaan berbagai kecakapan atau keterampilan hidup f) menggunakan berbagai media atau permainan edukatif g) dilaksanakan secara bertahap dan berulang (Suyadi,2009:12).

Pelaksanaan pembelajaran pada anak usia dini perlu memperhatikan cara kerja yang tersistem dan teratur guna memudahkan proses pembelajaran. Metode merupakan salah satu upaya mensistemkan pembelajaran seperti yang dikemukakan oleh Mursid (2015:26) yaitu metode merupakan alat yang digunakan untuk mencapai tujuan dengan langkah-langkah yang telah tersistem dan teratur. Salah satu metode pada pendidikan anak usia dini adalah metode bermain sambil belajar. Bermain merupakan aktivitas yang paling disukai oleh seluruh orang terlebih lagi oleh anak usia dini yang dimana dunia mereka adalah bermain. Piaget dalam Mayesty (1990:42) menyatakan bermain merupakan kegiatan yang dilakukan berulang-ulang demi kesenangan. Bermain bagi anak usia dini merupakan wadah belajar secara tidak langung, aktivitas bermain juga dapat mengembangkan mental, spiritual, bahasa, sosial dan keterampilan motorik anak yang sangat penting dalam menunjang tahap perkembangan anak.

Perkembangan anak usia dini meliputi perkembangan kognitif, sosial emosional, bahasa, fisik motorik, dan nilai agama moral. Perkembangan kognitif anak usia dapat distimulasi melalui bermain, karena bagi anak bermain adalah hidup dan hidup adalah permainan (Mayesty, 1990). Semua anak senang bermain, setiap anak menyukai permainan karena melalui bermain anak belajar untuk memahami lingkungan sekitar. Salah satu bentuk bermain yang dapat mengembangkan kognitif yaitu bermain simbolik. Bermain simbolik menurut Vygotsky dalam Naughton (2003) adalah bermain dengan cara memainkan peran, dengan begitu bermain tersebut penting dalam berfikir abstrak. Apabila anak sudah mulai bermain pura-pura, maka anak menjadi mampu berfikir tentang makna objek yang telah direpresentasikan secara independen.

\section{PERKEMBANGAN KOGNITIF ANAK USIA DINI}

Kognitif merupakan proses berfikir anak, dimana memunculkan kemampuan menghubungkan, menilai dan mempertimbangkan kejadian atau peristiwa. Pengertian kognitif menurut Piaget (dalam Musbikin, 2010:56) adalah kemampuan seseorang merasakan dan mengingat, serta membuat alasan untuk berimajinasi. Perkembangan kognitif tidak hanya meliputi matematika dan sains, namun juga pemecahan 
masalah (Santrock, 2007:50) dan penguasaan konsep (Schunk, 2012), hal tersebut dapat dikembangkan melalui sosial dan budaya sekitar anak. Menurut Billett (2017) kognisi manusia lebih dari kepandaian individu dan dibentuk melalui kontribusi dari dunia sosial. Sejalan dengan pendapat Billett, Wong (2017) berpendapat bahwa dalam perkembangan kognitif anak usia dini dapat dikembangkan melalui interkasi. Interaksi dapat dilakukan dengan cara bermain atau dengan benda-benda yang ada disekitar.

Perkembangan kognitif anak usia dini berbeda dengan anak usia selanjutnya. Menurut Piaget (dalam Salkind, 2009:326) Perkembangan kognitif anak usia 0-2 Tahun berada pada tahap sensorimotor dimana bayi memahami dunia melalui tindakan fisik dan nyata terhadap rangsangan dari luar. Perilaku berkembang dari refleks-refleks sederhana melalui beberapa tahap menuju seperangkat skema yang terorganisasi (perilaku yang terorganisasi) sedangkan anak usia 2-7 Tahun berada pada tahap pra oprasional dimana anak dalam tahapan ini masih berfikir simbolik dan bahasa sudah mulai jelas terlihat untuk menggambarkan objek dan kejadian, namun cara berfikir anak belum logis dan belum menyerupai orang dewasa.

Anak usia dini yang berada pada tahap praoprasional, berfikir secara simbolik. Pemikiran simbolis membuat anak mampu untuk membuat susunan kata dan gambar yang menggambarkan suatu objek atau tindakan tertentu dalam pikiran anak, sehingga jika dikaitkan dalam penyampaian pembelajaran, anak dalam tahapan ini memerlukan sebuah media konkret untuk dapat membantu anak dalam mencapai tingkat ketercapaian pembelajaran. Hal tersebut juga didukung oleh Beaty (2014) bahwa anak usia 2-7 Tahun masih sering terkecoh oleh tampilan misalnya wadah tinggi dan kecil yang berisi air lebih banyak daripada yang ada pada wadah yang pendek dan lebar serta anak belajar menduga efek satu tindakan ketika anak menuang susu dari wadah ke gelas akan menjadikan berkurang pada susu yang ada di wadah.

Perkembangan kognitif tahap praoprasional menurut Monks (1999:221) dimulai dengan penguasaan bahasa yang sistematis, permainan simbolis, imitasi dan bayangan dalam mental. Hal ini memberikan kita gambaran bahwa pola pikir anak pada tahapan ini masih bersifat egosentris karena anak hanya akan berfikir melalui sudut pandang mereka sendiri, mereka tidak dapat memahami tempatnya di dunia dan bagaimana hal tersebut berhubungan satu sama lain, anak kesulitan untuk memahami perasaan orang di sekitarnya dan belum bisa menyusun pikiran kearah yang sebaliknya. Untuk itu sangat diperlukan pemberian rangsangan untuk mengembangkan kognitif anak untuk menunjang tahapan selanjutnya.

Pengembangan kognitif pada anak usia dini bertujuan untuk 
mengembangkan kemampuan berfikir anak dalam mengolah pemerolehan belajar, dapat mengemukakan macam-macam alternatif pemecahan masalah, membantu anak untuk mengembangkan logika matematis dan pengetahuan akan ruang dan waktu, selain itu juga anak dilatih untuk memiliki kemampuan dalam memilah, mengelompokkan, serta mempersiapkan kemampuan berfikir secara teliti (Suyadi \& Dahlia, 2015: 40). Dari tujuan ini diharapkan terciptanya anak yang memiliki kreativitas, inovasi dan pemikir yang keritis guna menghadapi dunia yang dinamis.

Kognitif merupakan kemampuan yang erat hubungannya dengan pengetahuan yang diperoleh oleh individu serta cara berfikir individu terhadap suatu kejadian, tindakan dan apa yang diamati di sekitarnya. Cepat tidaknya individu dalam menyelesaikan masalah sangat bergantung pada perkembangan kognitifnya. Oleh karena itu, pengembangan kognitif individu memiliki peran yang cukup besar dalam perkembangan potensi yang ada dalam diri anak untuk tahap berikutnya.

\section{PERMAINAN EDUKATIF}

Banyak sekali jenis-jenis permainan untuk anak usia dini yang bisa dimainkan oleh anak. Namun sebaiknya jika permaian itu bisa mengembangkan aspek-aspek perkembangan anak. Penggunaan permainan pada anak usia dini adalah sebuah jalan untuk mengenal diri mereka sendiri dan menemukan dunianya selain itu permainan juga penting sebagai wahana dalam belajar (Cambridge University Press, 2014) sehingga dalam memnggunakan permainan yang akan dilakukan oleh anak, pihak orang tua dan guru hendaknya melihat unsur keedukatifan.

Permainan edukatif merupakan segala bentuk permainan yang dirancang agar memberikan manfaat pengalaman pendidikan atau pengalaman belajar kepada pemainnya termasuk anak-anak. Menurut Khobir (2009) permainan edukatif yaitu suatu kegiatan yang menyenangkan dan merupakan cara atau alat pendidikan yang bersifat mendidik. Permainan edukatif memiliki sifat-sifat seperti bongakar pasang, pengelompokan, memadukan, mencari padanan, merangkai, membantuk, menyusun dan lain sebagainya. Namun setiap permainan yang diterapkan di sekolah harus melihat media, tempat, kecocokan dan tingkat kesukaran dari permainan itu sendiri. Mulyasa (2012:167) menyatakan bahwa bermain yang dijadikan sebagai pendekatan pembelajaran hendaknya memperhatikan tahapan perkembangan anak. Dengan demikian dalam bermain harus memperhatikan kematangan atau perkembangan anak, alat yang akan digunakan, dan tempat bermain anak itu sendiri.

Permainan edukatif tidak hanya meliputi permainan modern namun juga permainan tradisional. 
Permainan modern tidak harus mahal, hanya saja yang perlu orang tua pahami adalah kegunaan dari permainan itu sendiri. Menurut Indrijati (2017:66) ada beberapa kriteria yang perlu dipenuhi ketika akan membeli permainan agar bermanfaat dan bersifat mendidik bagi anak yaitu yang pertama dapat merangsang aktivitas fisik agar tubuh menjadi sehat, yang kedua aman bagi kesehatan dan fisik, yang ketiga dapat membantu anak untu mengeksplorasi dan bereksperimen, yang keempat dapat dibongkar pasang, yang kelima dapat memotivasi anak meniru perilaku dan cara berfikir orang dewasa. Permainan tradisonal juga berpengaruh seperti yang telah diungkapkan oleh Indrijati (2017:66) bahwa permainan tradisional penting untuk anak untuk menjaga warisan budaya dan memperkenalkan anak dengan permainan tradisional daerah serta dalam permainan tradisonal memiliki variatif dalam setiap permainannya.

Contoh permainan edukatif dalam meningkatkan kognitif anak adalah bermain puzzle, bermain puzzle merupakan permainan menyusun suatu bentuk atau gambar tertentu. Menurut Soetjiningsih (1995:110) contoh alat permainan anak yang dapat menstimulus kognitif adalah puzzle. Puzzle merupakan permainan yang dapat meningkatkan kognitif anak karena bermain puzzle anak akan mencoba memecahkan masalah yaitu menyusun gambar. Hal tersebut didukung oleh penelitian yang dilakukan oleh Veronica (2015) bahwa aspek kognitif anak usia 5-6 Tahun meningkat sebesar 94,73\% melalui permainan tebak namaku yang didalam permainan tersebut merupakan permainan menyusun puzzle.

Permainan edukatif dalam meningkatkan kognitif tidak hanya bermain puzzle, namun juga bermain peran. Bermain peran merupakan permainan yang menggunakan konsep berpura-pura menjadi tokoh tertentu misalkan berpura-pura sebagai ibu, ayah atau orang berjualan. Bermain peran yang dilakukan oleh anak biasanya menggunakan benda-benda yang ada disekitar. Hal tersebut dapat mendukung anak untuk mengembangkan aspek perkembangan, salah satunya adalah aspek kognitif, karena anak belajar menggunakan benda-benda nyata dan belum bisa berfikir secara abstrak.

Keefektifan dari bermain peran juga diungkapkan Worthington\&Oers (2016) melalui hasil risetnya pada anak usia 3-4 sebanyak 7 anak di KotaBarat Daya Inggris, menunjukkan bahwa aktivitas bermain peran yang berkaitan dengan ilmu matematika meningkat sepanjang tahun, serta menunjukkan bagaimana pengetahuan anak-anak akan budaya di rumah mendukung permainan peran ini dan mampu mengedukasi anak dalam hal matematika.

Salah satu permainan tradisonal yang bisa meningkatkan perkembangan kognitif adalah congklak. Permainan congklak merupakan permainan yang sering 
dilakukan oleh anak. Alat untuk memainkan permainan ini adalah biji congklak dan papan uang yang ada 16 lubang untuk menyimpan biji congklak. Permainan ini biasanya dilakukan oleh dua orang pemain, kemudian biji congklak dibagi sama rata dan anak secara bergantian manaru biji congklak di lubnag papan uang. Dari kegiatan tersebut anak bisa berlatih menghitung dan hal terbut didukung oleh peneletian yang dilakukan oleh Heryanti (2014) bahwa perkembangan kognitif anak usia 5-6 Tahun meningkat sebesar $75 \%$ melalui permainan congklak.

\section{KESIMPULAN}

Berdasarkan kajian teori yang telah dipaparkan dapat disimpulkan bahwa perkembangan kognitif anak usia dini dapat berkembang melalui permainan edukatif, baik permainan edukatif yang modern maupun tradisonal. Sehingga orang tua dan guru dalam memilih permainan untuk anak harusnya memilih sesuai dengan kegunaan dan tujuan untuk perkembangan anak.

\section{DAFTAR PUSTAKA}

Beaty, J J. (2014). Observasi Perkembangan Anak Usia Dini. Jakarta: Kencana Prenada Media Group.

Billett, S. (2017). Theorising the Cooccurrence of Remaking Occupational Practices and Their Learning. Practice Theory Perspectives on
Pedagogy and Education, 68-86. DOI: 10.1007/978981-10-3130-4_4.

Heryanti, Vera. (2014).Meningkatkan Perkembangan Kognitif Anak Melalui Permainan Tradisional (Congklak). Universitas Bengkulu.

Indrijati, Herdina. (2017). Psikologi Perkembangan dan Pendidikan Anak Usia Dini. Jakarta: Kencana Prenada Media Group.

Khobir, A. (2009). Upaya Mendidik Anak Melalui Permainan Edukatif. Jurnal Forum Tarbiyah. 7 (2) hlm 195-208 Mayesty, M. (1990). CreativeActivitis For Young Children4 th ed: Play, devlopment, and Creativity. New York: Delmark Publiser Inc.

Monks, F J., A M P Knoers., Haditono, S T. (1999). Psikologi Perkembangan: Pengantar dalam Berbagai Bagiannya. Yogyakarta: Gadjah Mada University Press.

Mulyasa, E. (2005).Menjadi Guru Profesional.Bandung:PT. Remaja Rosda Karya

Mursid. (2015). Belajar dan Pembalajaran Paud. Bandung: Rosdakarya.

Musbikin, I. (2010). Buku Pintar PAUD. Jogjakarta: Laksana.

Naughton, G Mac. (2003). Shaping Early Childhood: Learners, Curriculum and contexts. Midenhead, Berkshire: Open University Press. 
Salkind, N J. (2009). Teori-teori Perkembangan Manusia. Bandung: Nusa Media

Santrock, J W. (2007). Perkembangan Anak (Volume 1). Jakarta: Erlangga.

Schunk, D H., (2012). Learning Theories (Ed). Yogyakarta. Pustaka Pelajar.

Soetjiningsih. (1995). Tumbuh Kembang Anak. Jakarta: Buku Kedokteran EGC.

Sujiono, Y N. (2013). Konsep Dasar Pendidikan Anak Usia Dini. Jakarta:PT Indeks.

Suyadi\&Dahlia. (2014). Implementasi

Dan Inovasi Kurikulum Paud 2013. Program Pembelajaran Berbasis Multiple Intelligences. Bandung: PT Remaja Rosda karya.

Suyadi. (2009). Psikologi Belajar Paud.Yogyakarta: Pedagogja.

Veronica, Nina. (2015). Peningkatan Kemampuan Kognitif Melalui Permainan Tebak
Namaku pada Anak Kelompok B TK Dharma Wanita Sekargadung. Online dalam http://karya-ilmiahum.ac.id/index.php/KSDP/se arch/authors/view?fristName $=$ VERONICA\&affiliation $=$ Mahasiswa\&country=ID

Wong, R K S. (2017). Do Hong Kong Parents Engage in Learning Activities Conducive to Preschool Children's Mathematics Development?. Early Mathematics Learning and Development, 2, 165178. DOI: $10.1007 / 978-981-$ 10-2553-2_10.

Worthington, M., Oers, B V. (2016). Pretend Play and The Cultural Foundations of Mathematics. European Early Childhood Education Research Journal. 24 (1), 51-66. DOI: 10.1080/1350293X.2015.112 0520 . 